\title{
Effects of varying sweet lupin dietary inclusion levels on feather classes, leather traits and meat composition of feedlot ostriches
}

\author{
T.S. Brand ${ }^{1,2, \#}$, J.A. Engelbrecht ${ }^{2}$, J. van der Merwe ${ }^{2}$ \& L.C. Hoffman ${ }^{2}$ \\ ${ }^{1}$ Directorate: Animal Sciences, Department of Agriculture, Western Cape Government, Private Bag X1, Elsenburg, 7607, \\ South Africa \\ ${ }^{2}$ Department of Animal Sciences, University of Stellenbosch, Private Bag X1, Matieland, 7602, South Africa
}

(Received 5 July 2017; Accepted 2 October 2017; First published online 1 December 2017)

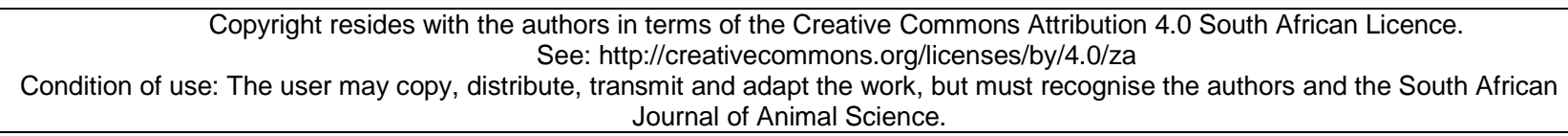

\begin{abstract}
The main consumer products derived from ostriches are feathers, leather and meat. Despite progress in optimizing production practices, additional information is still necessary about the value of various raw materials as feed to ensure cost-efficient production. This study aimed to determine the effects of the gradual replacement of soybean oilcake meal with sweet lupin (Lupinus angustifolius) seed in the diet of feedlot ostriches on the feather, leather and meat production characteristics. The chicks received a standard commercial pre-starter ostrich diet, with the trial utilizing 141 ostrich chicks ( \pm 10 chicks per group), beginning with the starter phase ( 83 days posthatching) and reared until 11 months of age. Five isonutritional diets were formulated for each feeding phase (starter, grower and finisher) according to specifications for each phase. In each phase, a control diet (Diet 1, 0\% lupin diet (LD)) was formulated using soybean oilcake meal as the sole protein source and Diet 5 (100LD) was formulated to include the maximum amount of sweet lupin according to the specifications for the species and feeding phase. The maximum amount of sweet lupin included in 100LD therefore differs among the three feeding phases. The remaining three diets were formulated by gradually replacing soybean oilcake meal with lupins in the following increments: $100: 0$ (0LD); $75: 25$ (25LD); $50: 50$ (50LD); $25: 75$ (75LD), and $0: 100$ (100LD). There were three replications per treatment, resulting in 15 groups of birds. Feed and water were supplied ad libitum. No differences were found for moisture, crude protein and ash contents of the meat. However, the intramuscular fat content was significantly influenced by the sweet lupin content of the diet. No differences were found for any of the feather classes that were measured. Regarding leather traits, the treatment diets had no effect on the crust sizes, leather grades, nodule diameters, and nodule densities. Differences were observed for leather thickness and pinhole number. It can be concluded that the sweet lupin inclusion levels evaluated in this study had little influence on leather traits, meat composition and feather classes.
\end{abstract}

Keywords: Diets, nutrition, ostrich products, slaughter ostriches

\#Corresponding author: tersb@elsenburg.com

\section{Introduction}

The modern ostrich industry has three economically important products, namely feathers, leather and meat, which are regarded as niche products (DAFF, 2014). The quality and yield of these products should be taken into account to ensure the cost-efficient production of slaughter birds (Engelbrecht, 2014). Currently, $90 \%$ of the value of a slaughtered bird is derived from the skin and meat ( $45 \%$ each) and the remaining $10 \%$ from feathers (DAFF, 2014). The ostrich industry makes a substantial contribution to the national economy, with South Africa being regarded as the world leader in ostrich products, supplying between $75 \%$ and $85 \%$ of the global market (Brand \& Jordaan, 2011; DAFF, 2014).

Ostrich feathers are exported to almost every continent, from South America to Asia, often being used as fashion products, especially in carnivals. Ostrich feathers are also used as industrial and household dusters, because of their unique ability to generate static electricity, attracting dust particles (Van Zyl, 2001; DAFF, 2014). Ostrich leather is regarded as a luxury product. Of all the exotic leathers, it is one of the most attractive, supple and durable (NAMC, 2010; Engelbrecht, 2014). The presence of feather follicles or nodules 
on ostrich leather gives it its unique appearance, while the nodule diameter and shape contribute to the quality of the leather (Meyer et al., 2004; Engelbrecht, 2014).

The value of ostrich meat and its health benefits were discovered only recently. Its low sodium, favourable fatty acid profile, low intra-muscular fat and cholesterol, and high iron and vitamin $E$ contents have resulted in consumers paying more attention to the ostrich as a meat source (Mellett, 1992; Sales \& Oliver-Lyons, 1996; Majewska et al., 2009; Poławska et al., 2011). However, little is known about the effect of production systems, in particular feed source, on the nutritional quality of this novel red meat alternative (Girolami et al., 2003; Poławska et al., 2011). Information on ostrich meat has become essential, because modern consumers want to be informed about the nutritional value of the food they consume (Sales et al., 1996; Horbańczuk \& Sales, 1998; Hoffman et al., 2005).

It remains a challenge to produce slaughter ostriches with high quality products with good profit margins. There is currently huge pressure on ostrich producers to farm as cost effectively as possible. Due to the high rearing costs of ostriches along with fluctuations in exchange rates and market trends it is difficult to ensure profitability and relevance of the ostrich industry in the agricultural sector. Feed costs make up the largest proportion of the input costs of an intensive ostrich production unit (ca. 75\%) (Brand et al., 2002; Brand \& Jordaan, 2011). A large part of these nutritional costs is represented by the protein source, with expensive soybean oilcake meal being the major source of protein in monogastric feeds throughout the world (Dalle Zotte et al., 2013; Snyman, 2016). Current widespread droughts, high costs of raw materials and the growing need for protein in human and animal diets globally (Brand et al., 2004a; AFMA, 2015) emphasize the need to investigate alternative protein sources for animal feed.

Oilseeds such as soybean, sunflower and cotton are common plant protein sources that are included in animal feeds, with soy being the most popular. Oilseed components are cultivated primarily in the summer rainfall areas of South Africa or have to be imported. Consequently, the costs of transportation, exchange rates, and market trends have a large influence on the price of these raw materials (NAMC, 2010).

Over the years, lupin (Lupinus angustifolius) has been identified as a potential locally produced plant protein source that could be fed to animals at a positive profit margin and could replace soybean oilcake meal as a raw material in ostrich diets. Currently, the price of sweet lupin (Lupinus angustifolius) is estimated to be $56 \%$ of that the value of soybean oilcake meal, making it a worthwhile economic alternative. If the cost associated with nutrition could be reduced, this would have a major impact on the profitability of a commercial ostrich production enterprise. Concerns have been raised due to the high presence of alkaloids in lupin seeds. Alkaloids are bitter tasting compounds that reduce the palatability of the feed. However, there are sweet (low in alkaloids, < $0.1 \%$ ) and bitter (alkaloid-rich, 0.1-4\%) varieties within the species (Breytenbach, 2005). In the 1950s and 1960s researchers in Western Australia concentrated on improving the agronomic characteristics and overcoming the bitter flavour of lupin. As a result, more palatable varieties of Lupinus angustifolius were cultivated successfully. These are frequently referred to as Australian sweet lupin, which distinguishes it from bitter varieties grown elsewhere (Petterson \& Fairbrother, 1996). However, lupin can still be included only up to certain maximum levels to be utilized efficiently and prevent undesirable effects (McDonald et al., 2011).

There is little literature on the inclusion of lupin in ostrich diets and the ways in which dietary inclusion might affect the production and quality of the meat, leather and feathers produced by slaughter birds. However, the use of locally produced feed sources would benefit the local grain legume industry and the ostrich industry and the potential of these sources is thus worth investigating. In an attempt to decrease the feeding costs of ostriches, least-cost diet formulations are applied by animal nutritionists and the use of lupin as a raw material could contribute to these formulations.

The aim of this study was to assess the influence of the gradual replacement of soybean oilcake meal with sweet lupin seed in the diets of feedlot ostriches on the major products, namely feather classes, leather traits (crust sizes, leather thickness, leather grades, nodule diameters and nodule and pinhole densities) and the nutritional value of the meat (Muscularis gastrocnemius).

\section{Materials and Methods}

Ethical approval (R14/108) for this study was obtained from the Western Cape Department of Agriculture. The trial was carried out from November 2014 to September 2015 at Kromme Rhee Research Farm near Stellenbosch, Western Cape, South Africa. The farm is situated at longitude $18^{\circ} 50^{\prime} \mathrm{E}$ and latitude $33^{\circ} 51^{\prime} \mathrm{S}$ with an altitude of $177 \mathrm{~m}$ above sea level.

Ostrich chicks used were obtained from the resource flock at Oudtshoorn Research Farm in the Little Klein Karoo region of South Africa (longitude $22^{\circ} 15^{\prime} \mathrm{E}$ and latitude $33^{\circ} 37^{\prime} \mathrm{S}$ at an altitude of $300 \mathrm{~m}$ above sea level) and transported after hatching to the experimental site. On arrival, the chicks were randomly divided into their five dietary treatment groups with three replications each, resulting in 15 groups. The chicks were initially reared indoors in 15 pens of $2.85 \mathrm{~m} \times 2.05 \mathrm{~m}$ per pen with free access to outdoor runs (14.60 $\mathrm{m}$ 
$x 1.80 \mathrm{~m}$ ) during the day. At nine weeks of age, the chicks were moved into outdoor paddocks of approximately $25 \mathrm{~m} \times 20 \mathrm{~m}$ to provide sufficient space to avoid unnecessary skin damage and leg abnormalities. The outdoor paddocks were equipped with adequate shelter for the ostriches and with sufficient feeding space. Mortalities were recorded, and dead birds were sent for post-mortem investigation throughout the experimental period to ensure that the dietary treatments were not responsible for these deaths. Most of the mortalities (37.3\%) occurred during the pre-starter phase which were mainly as a result of fractured legs, tibio-tarsal deformities, haemorrhagic enteritis, yolk sac infection, torsion of the intestine, and gastric stasis and dilatation, with no specific link to the trial diets.

Five iso-nutritional diets (Tables 1-3) were formulated for each of the starter, grower, and finisher phases using Mixit2+ software (Agricultural Software Consultants Inc., San Diego, USA), according to specifications determined by the model developed by Gous \& Brand (2008) for these feeding phases.

Table 1 Formulation and nutritional composition (as fed basis, $\mathrm{kg} / \mathrm{ton}$ ) of five treatment diets containing sweet lupin at various inclusion levels fed to starter phase slaughter ostriches from 83 to 167 days old

\begin{tabular}{|c|c|c|c|c|c|}
\hline \multirow{2}{*}{ Raw materials $(\mathbf{k g})$} & \multicolumn{5}{|c|}{ Diet (SOM replacement) and sweet lupin inclusion level (\%) } \\
\hline & OLD (0\%) & 25LD (5\%) & 50LD (10\%) & 75LD (15\%) & 100LD (20\%) \\
\hline Maize meal & 568.6 & 550.5 & 532.5 & 514.4 & 496.3 \\
\hline Soybean oilcake meal (SOM) & 180.0 & 147.5 & 115.0 & 82.5 & 50.0 \\
\hline Sweet lupin & 0.00 & 50.0 & 100.0 & 150.0 & 200.0 \\
\hline Lucerne meal & 140.0 & 140.0 & 140.0 & 140.0 & 140.0 \\
\hline Plant oil & 25.0 & 25.0 & 25.0 & 25.0 & 25.0 \\
\hline Molasses powder & 25.0 & 25.0 & 25.0 & 25.0 & 25.0 \\
\hline Monocalcium phosphate & 22.5 & 22.4 & 22.3 & 22.1 & 22.0 \\
\hline Limestone & 23.0 & 23.5 & 24.0 & 24.5 & 25.0 \\
\hline Salt & 10.0 & 10.0 & 10.0 & 10.0 & 10.0 \\
\hline Synthetic lysine & 2.40 & 2.60 & 2.80 & 3.00 & 3.20 \\
\hline Synthetic methionine & 0.00 & 0.00 & 0.00 & 0.00 & 0.00 \\
\hline Mineral and vitamin premix ${ }^{*}$ & 3.50 & 3.50 & 3.50 & 3.50 & 3.50 \\
\hline \multicolumn{6}{|l|}{ Nutrient composition } \\
\hline Metabolizable energy (MJ/kg feed) & 13.5 & 13.5 & 13.6 & 13.6 & 13.6 \\
\hline Crude fibre $(\mathrm{g} / \mathrm{kg})$ & 58.4 & 60.7 & 63.1 & 65.4 & 67.7 \\
\hline Ether extract $(\mathrm{g} / \mathrm{kg})$ & 52.1 & 56.0 & 60.0 & 63.9 & 67.8 \\
\hline Crude protein $(\mathrm{g} / \mathrm{kg})$ & 155.9 & 156.4 & 156.93 & 157.5 & 158.0 \\
\hline Lysine $(\mathrm{g} / \mathrm{kg})$ & 9.30 & 9.30 & 9.30 & 9.30 & 9.30 \\
\hline $\operatorname{TSA}(g / k g)^{\star \star}$ & 5.05 & 4.96 & 4.88 & 4.79 & 4.70 \\
\hline Threonine (g/kg) & 5.79 & 5.81 & 5.82 & 5.84 & 5.85 \\
\hline Tryptophan (g/kg) & 2.01 & 1.90 & 1.78 & 1.67 & 1.55 \\
\hline Arginine $(\mathrm{g} / \mathrm{kg})$ & 8.90 & 9.62 & 10.3 & 11.1 & 11.8 \\
\hline Ash (g/kg) & 20.9 & 20.7 & 20.6 & 20.5 & 20.4 \\
\hline Calcium (g/kg) & 15.0 & 15.0 & 15.0 & 15.0 & 15.0 \\
\hline Phosphorous (g/kg) & 7.88 & 7.72 & 7.57 & 7.41 & 7.25 \\
\hline Dry matter (g/kg) & 899.8 & 905.2 & 910.5 & 915.8 & 921.1 \\
\hline Total alkaloid content (ppm) & 0.00 & 2.45 & 4.91 & 7.37 & 9.82 \\
\hline
\end{tabular}


In each feeding phase, a control diet, Diet 1 (0\% lupin diet) (LD), was formulated with soybean oilcake meal as the sole protein source. Then Diet 5 (100LD) was formulated to include the maximum amount of sweet lupin according to the specifications for the species and feeding phase. The maximum amount of sweet lupin included in 100LD therefore differs among the feeding phases. The remaining three diets were formulated by incrementally adjusting the proportions of lupin sseeds and soybean oilcake in the diets between OLD and 100LD. Soybean oilcake meal was thus gradually replaced with sweet lupin in these ratios: $100: 0$ (0LD), 75 : 25 (25LD), $50: 50$ (50LD), $25: 75$ (75LD), and $0: 100$ (100LD). The raw material composition of the soybean oilcake meal and sweet lupin used in the diet formulations and nutrient composition of the dietary treatments can be found in Engelbrecht (2016). The diets were supplied ad libitum along with fresh water throughout the feeding phases.

Table 2 Formulation and nutritional composition (as fed basis, $\mathrm{kg} / \mathrm{ton}$ ) of five treatment diets containing sweet lupin at various inclusion levels fed to grower phase slaughter ostriches from 167 to 251 days old

\begin{tabular}{|c|c|c|c|c|c|}
\hline \multirow{2}{*}{ Raw materials $(\mathbf{k g})$} & \multicolumn{5}{|c|}{ Diet (SOM replacement) and sweet lupin inclusion level (\%) } \\
\hline & OLD (0\%) & 25LD (7.5\%) & 50LD (15\%) & 75LD (22.5\%) & 100LD (30\%) \\
\hline Maize meal & 590.6 & 544.9 & 499.2 & 453.5 & 407.8 \\
\hline Soybean oilcake meal (SOM) & 149.3 & 112.0 & 74.7 & 37.3 & 0.00 \\
\hline Sweet lupin & 0.00 & 76.5 & 152.9 & 226.5 & 300.0 \\
\hline Lucerne meal & 186.4 & 193.5 & 200.5 & 210.6 & 220.7 \\
\hline Molasses powder & 25.0 & 25.0 & 25.0 & 25.0 & 25.0 \\
\hline Monocalcium phosphate & 17.9 & 17.2 & 16.6 & 15.9 & 15.2 \\
\hline Limestone & 14.5 & 14.8 & 15.0 & 15.3 & 15.5 \\
\hline Salt & 10.0 & 10.0 & 10.0 & 10.0 & 10.0 \\
\hline Synthetic lysine & 0.87 & 0.76 & 0.65 & 0.53 & 0.42 \\
\hline Synthetic methionine & 0.41 & 0.43 & 0.45 & 0.46 & 0.48 \\
\hline Mineral and vitamin premix* & 5.00 & 5.00 & 5.00 & 5.00 & 5.00 \\
\hline \multicolumn{6}{|l|}{ Nutrient composition } \\
\hline Metabolizable energy (MJ/kg feed) & 12.8 & 12.8 & 12.8 & 12.8 & 12.8 \\
\hline Crude fibre (g/kg) & 68.7 & 73.8 & 78.8 & 83.8 & 88.9 \\
\hline Ether extract (g/kg) & 28.2 & 33.9 & 39.5 & 45.2 & 50.8 \\
\hline Crude protein $(\mathrm{g} / \mathrm{kg})$ & 150.5 & 156.0 & 161.5 & 167.0 & 172.4 \\
\hline Lysine $(\mathrm{g} / \mathrm{kg})$ & 7.67 & 7.67 & 7.67 & 7.67 & 7.67 \\
\hline TSA $(g / k g)^{* *}$ & 5.27 & 5.27 & 5.27 & 5.27 & 5.27 \\
\hline Threonine (g/kg) & 5.60 & 5.83 & 6.06 & 6.29 & 6.52 \\
\hline Tryptophan (g/kg) & 0.10 & 0.46 & 0.83 & 1.20 & 1.57 \\
\hline Arginine (g/kg) & 8.29 & 9.79 & 11.3 & 12.8 & 14.3 \\
\hline Ash $(g / k g)$ & 25.8 & 25.8 & 25.7 & 25.7 & 25.6 \\
\hline Calcium (g/kg) & 12.0 & 12.0 & 12.0 & 12.0 & 12.0 \\
\hline Phosphorous (g/kg) & 6.89 & 6.66 & 6.44 & 6.21 & 5.98 \\
\hline Dry matter (g/kg) & 896.4 & 904.7 & 913.0 & 921.3 & 929.6 \\
\hline Total alkaloid content (ppm) & 0.00 & 3.68 & 7.37 & 11.0 & 14.7 \\
\hline $\begin{array}{l}{ }^{*} \text { Refer to Appendix } 1 \text { for the compos } \\
\text { **Total sulphur containing amino aci } \\
\text { 0LD - } 0 \% \text { soybean oilcake replacem } \\
25 \text { LD - } 25 \% \text { soybean oilcake replac } \\
50 \text { LD }-50 \% \text { soybean oilcake replac } \\
75 \text { LD }-75 \% \text { soybean oilcake replac } \\
\text { 100LD }-100 \% \text { soybean oilcake repl }\end{array}$ & $\begin{array}{l}\text { the vitamin } \\
\text { with sweet lu } \\
\text { with sweet lu } \\
\text { with sweet lu }\end{array}$ & d mineral premi & for grower os & ches & \\
\hline
\end{tabular}


Table 3 Formulation and nutritional composition (as fed basis, $\mathrm{kg} / \mathrm{ton}$ ) of five treatment diets containing sweet lupin at various inclusion levels fed to finisher phase slaughter ostriches from 251 to 314 days old

\begin{tabular}{|c|c|c|c|c|c|}
\hline \multirow[b]{2}{*}{ Raw materials (kg) } & \multicolumn{5}{|c|}{ Diet (SOM replacement) and sweet lupin inclusion level (\%) } \\
\hline & $\begin{array}{l}\text { OLD } \\
(0 \%)\end{array}$ & $\begin{array}{c}25 \mathrm{LD} \\
(6.65 \%)\end{array}$ & $\begin{array}{c}\text { 50LD } \\
(13.29 \%)\end{array}$ & $\begin{array}{c}\text { 75LD } \\
(19.94 \%)\end{array}$ & $\begin{array}{c}\text { 100LD } \\
(26.58 \%)\end{array}$ \\
\hline Maize meal & 290.9 & 292.4 & 293.9 & 295.5 & 297.0 \\
\hline Oat hulls & 237.7 & 267.4 & 297.2 & 326.9 & 356.7 \\
\hline Wheat bran & 193.9 & 145.4 & 97.0 & 48.5 & 0.00 \\
\hline Soybean oilcake meal (SOM) & 82.7 & 62.0 & 41.3 & 20.7 & 0.00 \\
\hline Sweet lupin & 0.00 & 66.5 & 132.9 & 199.4 & 265.8 \\
\hline Lucerne meal & 126.0 & 94.5 & 63.0 & 31.5 & 0.00 \\
\hline Molasses powder & 24.2 & 24.4 & 24.5 & 24.6 & 24.7 \\
\hline Monocalcium phosphate & 12.2 & 12.1 & 11.9 & 11.8 & 11.7 \\
\hline Limestone & 17.9 & 20.5 & 23.1 & 25.8 & 28.4 \\
\hline Salt & 9.70 & 9.75 & 9.80 & 9.85 & 9.90 \\
\hline Synthetic methionine & 0.00 & 0.25 & 0.50 & 0.74 & 0.99 \\
\hline Mineral and vitamin premix* & 4.85 & 4.88 & 4.90 & 4.93 & 4.95 \\
\hline \multicolumn{6}{|l|}{ Nutrient composition } \\
\hline Metabolizable energy (MJ/kg feed) & 10.7 & 10.8 & 10.8 & 10.9 & 11.0 \\
\hline Crude fibre $(\mathrm{g} / \mathrm{kg})$ & 135.4 & 135.6 & 135.8 & 136.03 & 136.2 \\
\hline Ether extract (g/kg) & 23.6 & 28.3 & 33.1 & 37.8 & 42.6 \\
\hline Crude protein $(\mathrm{g} / \mathrm{kg})$ & 126.0 & 127.4 & 128.8 & 130.2 & 131.6 \\
\hline Lysine $(\mathrm{g} / \mathrm{kg})$ & 5.50 & 5.50 & 5.50 & 5.50 & 5.50 \\
\hline TSA $(g / k g)^{\star \star}$ & 4.04 & 4.04 & 4.04 & 4.04 & 4.04 \\
\hline Threonine $(\mathrm{g} / \mathrm{kg})$ & 4.46 & 4.54 & 4.62 & 4.69 & 4.77 \\
\hline Tryptophan $(\mathrm{g} / \mathrm{kg})$ & 1.72 & 1.59 & 1.45 & 1.32 & 1.18 \\
\hline Arginine $(\mathrm{g} / \mathrm{kg})$ & 6.98 & 8.15 & 9.33 & 10.5 & 11.7 \\
\hline Ash $(\mathrm{g} / \mathrm{kg})$ & 43.2 & 38.8 & 34.5 & 30.1 & 25.7 \\
\hline Calcium $(\mathrm{g} / \mathrm{kg})$ & 12.0 & 12.5 & 13.0 & 13.5 & 14.0 \\
\hline Phosphorous (g/kg) & 6.81 & 6.29 & 5.78 & 5.26 & 4.74 \\
\hline Dry matter $(\mathrm{g} / \mathrm{kg})$ & 901.6 & 909.2 & 916.7 & 924.3 & 931.9 \\
\hline Total alkaloid content (ppm) & 0.00 & 3.27 & 6.53 & 9.79 & 13.1 \\
\hline
\end{tabular}

${ }^{*}$ Refer to Appendix 1 for the composition of the vitamin and mineral premix for grower ostriches

${ }^{* *}$ Total sulphur containing amino acids

OLD - $0 \%$ soybean oilcake replacement

$25 \mathrm{LD}-25 \%$ soybean oilcake replacement with sweet lupins

$50 \mathrm{LD}-50 \%$ soybean oilcake replacement with sweet lupins

75 LD - 75\% soybean oilcake replacement with sweet lupins

100 LD - $100 \%$ soybean oilcake replacement with sweet lupins

The birds were reared under this condition for ca. 11 months of age, after which they were slaughtered at Mosstrich, a registered abattoir in Mossel Bay, Western Cape. The birds were slaughtered according to standard ostrich slaughter, as described by Hoffman (2012). After exsanguination, the feathers of each bird were plucked by hand and kept separately in individually marked bags, which were transported to the feather department of Klein Karoo International (KKI) Ltd in Oudtshoorn for drying and classification. After flaying the ostrich skins, the skins of each bird were marked and transported to Southern Cape Ostrich Tanning (SCOT) for further processing. After slaughter and evisceration, the carcasses were stored in the on-site cold storage facilities $\left(0-2{ }^{\circ} \mathrm{C}\right)$ for 18 hours before deboning commenced. During deboning, the big drum muscle $(M$. gastrocnemius) was removed from the right thigh of each ostrich and weighed. Big drum samples selected 
from 10 birds per treatment, which were chosen around the median slaughter weights of the birds for each diet, were collected and transported back to Stellenbosch University for further chemical analysis.

It is considered to be normal industry practice to clip the ripe feathers from ostriches at six months old or a live weight of $60 \mathrm{~kg}$ or more to ensure a good feather crop at slaughter (12 months old). However, the harvesting of immature or green/blood feathers is not permitted because of welfare concerns (Engelbrecht, 2014), and plucking stretches the follicles, which affects leather quality negatively (Engelbrecht et al., 2009). In this trial, the birds were not clipped or plucked at six months of age, as they still had blood feathers, and they were slaughtered at ca. 11 months old rather than 12 months old, so there would not have been adequate time for the new feathers to grow and be ripe at slaughter. Ostriches sometimes also show a slight decline in weight after feather harvesting, with a greater effect being seen during the winter months. Therefore feathers were not plucked in order to ensure optimal growth of the birds.

At Klein Karoo International Feather Department, the feathers of each bird were weighed and placed into a large oven set at $50^{\circ} \mathrm{C}$. The feathers were dried for 48 hours. In the last half hour of drying, the temperature was increased to $70{ }^{\circ} \mathrm{C}$ for sterilization. As the individual feather batches were removed from the oven, they were weighed again to calculate the amount of moisture lost during the drying process. The feather batches per bird were then separated into their economically important classes, namely 'marketable and unmarketable feathers', 'chick wing', 'drab silver floss', 'chick body short', 'chick blondene floss', 'chick tail' and 'ruggies' (back feathers), and graded by qualified graders. The descriptions of these feather classes are listed in Table 4. The weight of each class of feathers was recorded for statistical analysis.

Table 4 Descriptions of economically important feather classes in this study

\begin{tabular}{ll}
\hline Feather classes & Area of body and description \\
\hline Unmarketable & $\begin{array}{l}\text { Do not meet the grading standards set out by the industry; these feathers originate from } \\
\text { the wings, body and tail of the bird } \\
\text { White plumes in the first row of prominent plumes at the edge of the wing } \\
\text { Chick wing }\end{array}$ \\
$\begin{array}{l}\text { Soft body feather found on the ventral side of the bird; generally shorter in length. The } \\
\text { feather classes classified as 'drab' are normally feathers that are shorter than the wing } \\
\text { feathers because of their location on the body }\end{array}$ \\
$\begin{array}{l}\text { Body feathers from behind the thighs to the tail } \\
\text { Chick body short }\end{array}$ \\
$\begin{array}{l}\text { Soft body feather on the wings of the bird. The only soft feather on the wings } \\
\text { Chick tail }\end{array}$ & $\begin{array}{l}\text { Body feather found on the tail of the bird } \\
\text { Back feathers }\end{array}$ \\
\hline
\end{tabular}

The tanning of the skins started soon after slaughter. ${ }^{1}$ After the subcutaneous fat had been removed from the raw skin by a process of hand fleshing, each skin was assigned a marked microchip for identification along the tanning process. The removal of the fat allows full penetration of the skin by the preservative chemicals involved in tanning and makes the skin surface thinner and more even. A quality control check was done to determine whether damage had occurred during the slaughtering process, before the skins were classed into weight groups. This involves weighing the skins and dividing them into specific weight classes so that the tanning chemicals could be adjusted appropriately. The skins were then placed in the tanning drums to undergo soaking, de-hairing, and liming. The $\mathrm{pH}$ in the drum was increased to 9.5 during the soaking process, 11.5 for de-hairing and then up to 13.5 for liming. The revolutions per minute (rpm) of the drum were 4 rpm for 24 hours for soaking and 22 rpm for 24 hours for de-hairing and liming. Next, the skins were exposed to various enzymes to break down the soluble proteins and fats that remained in the skin, without causing damage to the skin itself. This process is referred to as 'bating'. Afterwards, the skins went through a process of 'pickling', which involves subjecting them to a salt and acid solution to prepare them for bleaching. For better penetration of the chemicals in the subsequent steps, the loose fibres from each skin were shaved off. During the degreasing process, the skins were subjected to a saponification agent specially manufactured for ostrich skins. A phase known as 're-tanning' followed. Here the style of the individual tanner becomes evident in the leather characteristics. Care was taken to ensure that the same tanner worked on all the experimental skins. Because of the residual fat content, an industrial tumble drier

\footnotetext{
${ }^{1}$ Because of intellectual property, details of the tanning process cannot be reported. However, care was taken to ensure that all skins received the same treatment.
} 
was then used to dry the skins. The skins were also tumbled along with a cattle hide to make the leather more soft and durable. Then, the dry crust size $\left(\mathrm{dm}^{2}\right)$ was measured and the skins were sorted and graded (subjective evaluation) by qualified graders. Grading of the skins was done by visual inspection of the crown area of the skin. The crown area is divided into four quadrants and inspected for blemishes and damages. If there are no blemishes, or blemishes are confined to only a single quarter, the skin is then graded as first grade. If there is blemishes are found in two quarters, it is given a grade of two. If further blemishing is found in quadrants three and four, the skins are given a grade of three or four, respectively. The skins were then stored in their chrome-crusted form for transport to Elsenburg Research Institute for measurement of the quality traits.

The crust size $\left(\mathrm{dm}^{2}\right)$ and grading of the leather for each bird were obtained from the tannery (SCOT, 2016). The leather thickness ( $\mathrm{mm}$ ) was measured with Mitutoyo digital callipers (model number CD-8" C) on the right-hand side of the skin, next to and outside the crown area, as described by Engelbrecht (2013). Three separate measurements were taken to obtain an average thickness for each crust. The leather appearance of each bird was evaluated at five localities: neck, mid-crown, upper leg, lower flank and butt. The base diameter of five randomly selected nodules per $1 \mathrm{dm}^{2}$ sampling site was also measured with Mitutoyo digital callipers and an average calculated per treatment. In addition, the number of nodules in the 1 $\mathrm{dm}^{2}$ was counted and then the number of pinholesin a smaller $5 \mathrm{~cm} \times 5 \mathrm{~cm}$ area within the $1 \mathrm{dm}^{2}$ square area to determine the nodule and pinhole density per locality.

The median slaughter weight of the birds was identified for each of the treatment groups and 10 ostriches per treatment around the median were selected for sampling the meat quality by chemical analysis. The big drum muscle ( $M$. gastrocnemius) of the right thigh was used to perform proximate analysis after the subcutaneous fat had been removed and the meat had been homogenized. The samples were analysed according to the methods of the Association of Official Analytical Chemists (AOAC) for moisture, ash, crude protein and crude fat (AOAC, 2002). The moisture content (\%) was determined using method 934.01 (moisture loss on drying at $95-100{ }^{\circ} \mathrm{C}$ ) and then the ash content was determined on the moisture-free sample with method 942.05. Method 992.15 (Dumas combustion method) was used to determine the crude protein $(\mathrm{N} \times 6.25)$ content of the meat sample. Finally extraction method 920.39 , chloroform/methanol $(1: 2$ $\mathrm{vol} / \mathrm{vol}$ ), was used to determine the crude fat content.

Statistical analysis was done using SAS enterprise guide version 9.2 (SAS Institute Inc., Cary, USA). The feather traits and classes, leather traits and chemical components of the meat were investigated by performing one-way analysis of variance (ANOVA) to determine whether the treatment diets had any effect over the experimental period. To test for normality, the Shapiro-Wilk test was conducted (Shapiro \& Wilk, 1965). Outliers were identified and removed prior to final analysis. The t-least significant differences were calculated on a $5 \%$ significance level. The resulting differences were deemed to be significant at the $P<0.05$ level.

\section{Results}

The treatment diets had no effect on total average dry feather weight and total average dry feather weight marketable. Similarly, no differences were observed between the diets for any of the feather classes. The mean marketable feather yield in this trial was $646.6 \pm 20.1 \mathrm{~g}$.

Regarding the leather traits in Table 5, no differences were found in the mean grade allocated to the leather of the birds in the treatment groups. No differences were observed among the groups for the crust size (with a mean of $\left.140.2 \pm 1.51 \mathrm{dm}^{2}\right)$, but differences $(P=0.03)$ were observed for leather thickness. The leather of the birds on 25LD was significantly thicker (9.8\%) than that of the birds receiving OLD, 50LD, $75 \mathrm{LD}$, and 100LD. In this study, the mean leather thickness was $0.88 \pm 0.02 \mathrm{~mm}$.

In terms of nodule diameters and nodule and pinhole densities, no differences were found among treatment diets in the five locations on the leather.

No differences for the treatment groups were observed in the moisture, crude protein and ash contents of the meat (Table 6). However, a significant difference $(P=0.03)$ was observed in the intramuscular fat (IMF) content. The IMF of birds in the 50LD and 75LD groups was significantly higher than that of the 0LD and 100LD diets, while that of the 25LD did not differ from the 75LD, but was in turn lower than that of the $50 \mathrm{LD}$

\section{Discussion}

This study is intended to contribute to the limited knowledge of ostrich nutrition (Brand et al., 2014), and its effect on end products.

The mean marketable feather yield in this study was found to be $646.6 \pm 20.1 \mathrm{~g}$. No significant differences were found for the marketable feather yield between diets with different sweet lupin inclusion levels. Carstens (2013) and Viviers (2015), also found no differences in marketable feather yields for 
ostriches reared on diets with similar energy $(7.5-15.5 \mathrm{MJ} / \mathrm{kg}$ feed) and protein $(117.7-234.8 \mathrm{~g} / \mathrm{kg})$ contents. However, these studies reported yields that were slightly higher than the results obtained from this study. This is mainly due to the differences in slaughter ages of the birds in the different experiments. Carstens (2013) also found that the quantity of marketable feathers was significantly higher (10.7\%) for birds whose feathers were clipped. If the feathers are not harvested initially, the development of mature feathers then takes place at a later stage. According to Carstens (2013), new feather development starts directly after the initial feathers are harvested. The large number of chick feather classes observed in the grading of feathers harvested from birds in this sweet lupin trial, could be as a result of the feathers not harvested at six to eight months of age, which would have then resulted in a reduction in growth of the birds during the winter. Research on feather growth and quality has been limited owing to this product contributing only a small portion $(\sim 10 \%)$ of the total income of a slaughter bird. However, it may be beneficial to the industry to determine the importance of feather clipping and what stage they should be clipped when slaughtering at 12 to 14 months old if the feathers are not ripe at six to eight months.

Table 5 Least square means for the effect of sweet lupin dietary inclusion levels on some leather traits of slaughter ostriches ( 11 months old) at the end of the experimental period

\begin{tabular}{lccccccc}
\hline \multirow{2}{*}{ Leather traits } & \multirow{2}{*}{ Average } & \multicolumn{7}{c}{ Diets } & SE \\
\cline { 3 - 6 } & & OLD & 25LD & 50LD & 75LD & 100LD & \\
\hline Mean grading & 2.3 & 2.5 & 2.14 & 2.3 & 2.3 & 2.4 & 0.4 \\
Crust size $\left(\mathrm{dm}^{2}\right)$ & 140.9 & 136.4 & 141.9 & 144.2 & 141.4 & 136.9 & 2.9 \\
Thickness $(\mathrm{mm})$ & 0.88 & $0.83^{\mathrm{a}}$ & $0.95^{\mathrm{b}}$ & $0.88^{\mathrm{a}}$ & $0.87^{\mathrm{a}}$ & $0.88^{\mathrm{a}}$ & 0.02 \\
\hline
\end{tabular}

${ }^{a, b, c}$ Row means with different superscripts differ significantly $(P<0.05)$

OLD - $0 \%$ soybean oilcake replacement

$25 \mathrm{LD}-25 \%$ soybean oilcake replacement with sweet lupins

$50 \mathrm{LD}-50 \%$ soybean oilcake replacement with sweet lupins

$75 \mathrm{LD}-75 \%$ soybean oilcake replacement with sweet lupins

$100 \mathrm{LD}-100 \%$ soybean oilcake replacement with sweet lupins

Table 6 Least square means and standard error for proximate analysis of big drum muscle of slaughter ostriches fed diets with various sweet lupin inclusion levels (100\% dry matter basis except for moisture)

\begin{tabular}{|c|c|c|c|c|c|c|c|}
\hline \multirow{2}{*}{$\begin{array}{l}\text { Chemical } \\
\text { component }(\mathrm{g} / \mathrm{kg})\end{array}$} & \multirow{2}{*}{ Average } & \multicolumn{5}{|c|}{ Diets } & \multirow{2}{*}{ SE } \\
\hline & & OLD & 25LD & 50LD & 75LD & 100LD & \\
\hline Moisture & 763.8 & 765.6 & 761.9 & 764.3 & 760.9 & 766.5 & 2.3 \\
\hline Crude protein & 206.9 & 206.2 & 210.3 & 205.8 & 207.9 & 204.5 & 2.5 \\
\hline Crude fat & 25.6 & $23.5^{\mathrm{a}}$ & $24.6^{\mathrm{ab}}$ & $28.6^{c}$ & $28.0^{\mathrm{bc}}$ & $23.3^{\mathrm{a}}$ & 1.2 \\
\hline Ash & 11.7 & 11.0 & 12.5 & 11.2 & 11.9 & 12.0 & 0.5 \\
\hline
\end{tabular}

No significant differences were observed in the crust size of the skins from birds that were supplied sweet lupin at various inclusion levels. The mean crust size in this trial was found to be $140.2 \pm 1.51 \mathrm{dm}^{2}$. A significant difference was observed in the leather thickness of the treatment birds, with the birds receiving 25LD having the thickest $(0.95 \pm 0.02 \mathrm{~mm})$ leather. This corresponds with the slaughter weights of the birds, as the birds on 25LD had the highest slaughter weight $(93.2 \pm 2.15 \mathrm{~kg})$, although the differences in slaughter weight were not deemed to be significant (Engelbrecht, 2016). No significant differences were observed among the diets for the leather grades. Across all the dietary treatments, Grade 2 leathers were found to be the most prevalent. These results are supported by Brand et al. (2004b) and Viviers (2015), who also found that the majority of the ostrich leathers were of grade 2 quality, however, the leather grades did not differ significantly between diets with different levels of energy and protein. 
The nodules found on ostrich leather products give the leather its lucrative aesthetic appeal, with the size of the nodules influencing its visual appearance. Nodule diameter showed no significant differences between the treatments at the various locations and values were similar to those obtained by Brand et al. (2004b) and Cloete et al. (2006b). The results indicate that the locality on the skin has a marked effect on the average nodule diameter and density: With the average nodule diameter on the neck $(3.00 \pm 0.03 \mathrm{~mm})$ and mid crown $(3.04 \pm 0.03 \mathrm{~mm}$ ) areas being smaller than those on the upper leg $(3.34 \pm 0.03 \mathrm{~mm})$, lower flank $(3.59 \pm 0.04 \mathrm{~mm})$ and butt $(3.65 \pm 0.03 \mathrm{~mm})$ regions. No significant differences in nodule density were found between the diets at the various localities. Nodule density was seen to decrease from the neck $(48.5 \pm 0.47)$ and mid crown $(60.1 \pm 0.51)$ areas towards the upper leg $(24.1 \pm 0.44)$ and lower flank $(35.7 \pm 0.26)$, while nearer to the back line (butt area) $(52.3 \pm 0.80)$ the nodule density increased. These observations correspond with work done by Cloete et al. (2004), Cloete et al. (2006b) and Engelbrecht et al. (2009).

The average nodule diameter usually increases with a decrease in nodule density, with the exception of the butt area, which has a high density of large nodules (Engelbrecht et al., 2009). The nodule density per locality overall was slightly lower than the values obtained by Cloete et al. (2004) and Cloete et al. (2006b). Meyer et al. (2004) stated that skin damage and size were the main factors that determine ostrich skin and leather grading. However, nodule diameter has also recently been incorporated as a grading factor. From the findings of Viviers (2015) it appears that dietary protein content may influence nodule diameter and density on some areas of the leather and this warrants further research. However varying the levels of protein source in the diets in this study did not affect the nodule diameter and density.

The dietary lupin content had an effect on the pinhole density at the lower flank. More pinholes were found on the leather of birds that received 25LD $(21.5 \pm 2.34)$ and 50LD $(21.4 \pm 2.34)$ than those who received 100LD $(12.9 \pm 2.34)$. The amount of pinholes at the lower flank per skin ranged from 12.9 to 21.5 . The pinhole density reported by Viviers (2015) was similar to that of the current study, with values ranging from 14.2 to 17.0 and 9.77 to 14.6 pinholes per skin for the energy and protein comparisons, respectively, however, these differences were not found to be significant. It must be considered that the number of pinholes is counted manually, which is difficult considering the minute size of the pinholes. This results in large deviations around the mean and could affect the results. It is thus not possible to confirm whether nutrition (energy, protein or sweet lupin inclusion levels) has an effect on pinhole density, although this does not appear to be the case (Viviers, 2015).

With regard to the chemical composition of the meat of the birds that consumed the sweet lupin diet, the mean moisture, crude protein and ash contents were found to be $763.8 \pm 1.07,206.9 \pm 1.00$, and $11.7 \pm$ $0.27 \mathrm{~g} / \mathrm{kg}$, respectively. No significant differences were observed for these chemical components between the treatment groups. The intra-muscular fat content was found to be $25.6 \pm 1.37 \mathrm{~g} / \mathrm{kg}$, and significant differences were observed among the groups with the IMF of the birds fed 50LD $(28.6 \pm 1.24 \mathrm{~g} / \mathrm{kg})$ being higher than the IMF of the birds that received the OLD $(23.5 \pm 1.24 \mathrm{~g} / \mathrm{kg})$ and $100 \mathrm{LD}(23.3 \pm 1.24 \mathrm{~g} / \mathrm{kg})$ diets.

The oil content of sweet lupin is $1.4 \%$ higher than that of soybean oilcake meal (Ewing, 1997; Feedipedia, 2016). For the starter, grower and finisher phases, the average total fat content of the control diets was $34.6 \mathrm{~g} / \mathrm{kg}$, compared to the average total fat content of $46.6 \mathrm{~g} / \mathrm{kg}$ for the other diets. In other words, the average total fat content of the experimental diets containing sweet lupin was $34.4 \%$ higher than that of the control diets, which were formulated with soybean oilcake meal as the sole protein source. Although the diets were formulated to be iso-nutritious in terms of metabolizable energy, protein and amino acids, the IMF content of the birds fed the intermediate diet was significantly higher than that of the birds fed OLD (control) and 100LD (maximum lupin inclusion level). This is contrary to the expectation that the birds fed 100LD would have the highest IMF. These findings do not correlate with that obtained by Carstens (2013) and Viviers (2015), who found no significant differences in the intra-muscular fat content of the meat of ostriches fed diets with different protein and energy contents.

Overall, the findings for the chemical composition of the meat are consistent and relate to the values obtained in previous studies. The moisture content of the meat at $763.8 \mathrm{~g} / \mathrm{kg}$ is slightly lower than in studies by Sales \& Oliver-Lyons (1996), Hoffman et al. (2005) and Majewska et al. (2009), which obtained moisture contents of $777.0,766.6$ and $767.0 \mathrm{~g} / \mathrm{kg}$, respectively. In studies by Sales \& Oliver-Lyons (1996), Sales \& Hayes (1996), Hoffman et al. (2005), Majewska et al. (2009), and Dalle Zotte et al. (2013) the ostrich meat had crude protein content of 206.0,211.2, 216.6, 213.0 and $212.0 \mathrm{~g} / \mathrm{kg}$, respectively. The current study compares well with those values, with a crude protein value of $206.9 \mathrm{~g} / \mathrm{kg}$. The crude fat content for this sweet lupin inclusion trial was higher at $25.6 \mathrm{~g} / \mathrm{kg}$ than studies by Sales \& Oliver-Lyons (1996) $(2.60 \mathrm{~g} / \mathrm{kg})$, Sales \& Hayes (1996) $(6.50 \mathrm{~g} / \mathrm{kg})$, Hoffman et al. (2005) $(20.5 \mathrm{~g} / \mathrm{kg})$, and Majewska et al. (2009) $(9.00 \mathrm{~g} / \mathrm{kg}$. However, it was lower than the crude fat measured in the study by Dalle Zotte et al. (2013) $(30.9 \mathrm{~g} / \mathrm{kg})$. Hoffman et al. (2005) had a slightly higher ash value of $12.2 \mathrm{~g} / \mathrm{kg}$, compared with $11.7 \mathrm{~g} / \mathrm{kg}$, which was obtained from his study. 
It can thus be seen that sweet lupin can be included in ostrich diets to replace soybean oilcake to produce feathers, leather and meat with uniform quality aspects, which compare well with that found in previous studies.

\section{Conclusion}

In this study, the quality aspects of the three ostrich products were evaluated post slaughter. No differences were found for the marketable feather classes. The feather yields of the birds in this study were slightly below values found in previous studies, as they were not initially harvested at $6-8$ months of age. The leather quality aspects were similar for all of the treatments, apart from ostriches on the 25LD having the thicker skins, which was due to the birds being slightly heavier at slaughter. Overall grade 2 skins were found to be most prevalent in this study. A tendency was found for birds that received 25LD and 75LD to have the highest pinhole densities at Locality 4 (the lower flank). However, the number of pinholes is counted by the human eye and is difficult to determine accurately, which could possibly affect the results. The chemical composition of the meat was fund to be similar, except that the intra-muscular fat content was influenced by the sweet lupin inclusion in the diet. This could be related to differences in feed intake of the birds, but may warrant further investigation. It can be concluded that the sweet lupin inclusion levels evaluated in this study had little influence on the feather classes, leather traits and the meat composition of the birds.

Overall, the results from this study are similar to those from previous studies. These findings assure producers that the sweet lupin inclusion levels evaluated in this study would yield similar quality returns to standard commercial slaughter ostrich diets that have soybean oilcake meal as the primary protein source. As the price of lupin is much lower than that of soybean oilcake meal, it is a worthwhile economic alternative. Results from this study will contribute to the limited knowledge of the nutritional value of sweet lupin as a raw material in ostrich rations. This knowledge could be used to formulate diets for ostriches more accurately and consequently improve the economical production of ostrich meat, leather and feathers. In addition, it would aid in developing the market for locally produced sweet lupin in South Africa, which would eventually benefit the local grain industry as well as the ostrich industry. Sweet lupins were evaluated only to maximum inclusion levels of $20 \%$ in the starter phase and $30 \%$ in the grower and finisher phases and so including sweet lupins in ostrich rations beyond these levels may result in findings that differ from the results reported in this study. However, ostrich producers can be assured that including sweet lupins in the diets of slaughter ostriches at these levels would yield similar quality returns to standard commercial slaughter ostrich diets, which are formulated with soybean oilcake meal as a protein source.

\section{Acknowledgements}

Acknowledgements are made to Western Cape Department of Agriculture for joint funding of the study, and to the personnel in their employment for their aid. In addition, the Western Cape Agricultural Research Trust are thanked for the joint funding of the study. Finally, Mosstrich abattoir in Mossel Bay are thanked for their willingness to accommodate the needs of the authors during the slaughter process and subsequent data collection.

\section{Authors' Contributions}

Concept and design, TSB; data collection and analysis, JAE; drafting of paper, JvdM; critical revision and final approval of version to be published, LCH. All the authors made substantial contributions to conception and design, acquisition of data, analysis and interpretation of data. All the authors have approved the manuscript being submitted.

\section{Conflict of Interest Declaration}

The authors certify that they have no affiliations with or involvement in any organization or entity with financial interest, or non-financial interest in the subject matter or materials discussed in this manuscript.

\section{References}

AFMA, 2015. Animal Feed Manufacturers Association Chairman's Report 2014/2015. AFMA's 68th Annual General Meeting, KwaZulu-Natal, South Africa, 4 September 2015. pp. 1-59.

AOAC, 2002. Official methods of analysis $\left(17^{\text {th }}\right.$ ed.). Association of Official Analytical Chemists, Inc., Arlington, Virginia, USA.

Brand, T.S. \& Jordaan, J.W., 2011. The contribution of the South African ostrich industry to the national economy. Appl. Anim. Husb. Rural Develop. 4, 1-7.

Brand, T.S., Brandt, D.A. \& Cruywagen, C.W., 2004a. Chemical composition, true metabolisable energy content and amino acid availability of grain legumes for poultry. S. Afr. J. Anim. Sci. 34, 116-122.

Brand, T.S., Carstens, P.D. \& Hoffman, L.C., 2014. The effect of dietary energy concentrations on production variables of ostrich chicks (Struthiocamelus var. domesticus). Brit. Poult. Sci. 55, 610-618.

Brand, T.S., Nel, K., Brand, Z. \& Schalkwyk, K., 2002. Recent advances in ostrich nutrition in South Africa: Effect of dietary energy and protein level on the performance of growing ostriches. S. Afr. J. Anim. Sci. 3, 1-8.

Brand, T.S., Gous, R.M., Kruger, A.C.M., Brand, Z., Nel, J., Aucamp, B.B. \& Engelbrecht, S., 2004b. Mathematical feeding optimization model for ostriches: Recent progress in the prediction of nutrient requirements for slaughter 
and breeder birds. Invited review at Ostrich Information Day of South African Ostrich Producers Organisation, June 2004, pp. 1-13 (in Afrikaans).

Carstens, P.D., 2013. Studies to develop a mathematical optimisation model to describe the effect of nutrition on the growth of ostriches (Struthio camelus var. domesticus). MSc(Agric) thesis, University of Stellenbosch, South Africa.

Cloete, S.W.P., Van Schalkwyk, S.J., Engelbrecht, A. \& Hoffman, L.C., 2006b. Genetic variation in nodule size at different sites on the skins of slaughter ostriches. S. Afr. J. Anim. Sci. 36, 160-164.

Cloete, S.W.P., Van Schalkwyk, S.J., Hoffman, L.C., \& Meyer, A., 2004. Effect of age on leather and skin traits of slaughter ostriches. S. Afr. J. Anim. Sci. 34, 80-86.

DAFF, 2014. A profile of the South African ostrich market value chain. Directorate: Marketing of the Department of Agriculture, Forestry and Fisheries. Available from http://www.nda.agric.za/doaDev/sideMenu/Marketing/Annual Publications/Commodity Profiles/Livestock/Ostrich market value chain profile 2014.pdf, pp. 1-41. Accessed 19 January 2016.

Dalle Zotte, A., Brand, T.S., Hoffman, L.C., Schoon, K., Cullere, M. \& Swart, R., 2013. Effect of cottonseed oilcake inclusion on ostrich growth performance and meat chemical composition. Meat Sci. 93, 194-200.

Engelbrecht, A., 2013. Establishing genetic and environmental parameters for ostrich (Struthio camelus domesticus) growth and slaughter characteristics. Ph.D. thesis, University of Stellenbosch, South Africa. Available from http://hdl.handle.net/10019.1/80204.

Engelbrecht, A., 2014. Slaughter-bird production and product quality. In: P. Jorgensen (ed.) Ostrich manual, pp. 75-85. Western Cape Department of Agriculture, South African Ostrich Business Chamber, Elsenburg, South Africa.

Engelbrecht, A., Hoffman, L.C., Cloete, S.W.P. \& Van Schalkwyk, S.J., 2009. Ostrich leather quality: A review. Anim. Prod. Sci. 49, 549-557.

Engelbrecht, J.A., 2016. The evaluation of lupins (Lupinus angustifolius) as alternative protein source to soybean oilcake meal in ostrich (Struthio camelus var. domesticus) diets. MSc (Agric) thesis, University of Stellenbosch, South Africa.

Ewing, I., 1997. Soya bean meal. In: The feeds directory, vol. 1, Commodity products, pp. 94-95 Contex, Leicestershire, England.

Feedipedia. 2016. Lupin (Lupinus angustifolius), blue, seeds. Available from http://www.feedipedia.org/node/12271 Accessed 12 July 2016.

Girolami, A., Marsico, I., D’Andrea, G., Braghieri, A., Napolitano, F. \& Cifuni, G.F., 2003. Fatty acid profile, cholesterol content and tenderness of ostrich meat as influenced by age at slaughter and muscle type. Meat Sci. 64, 309315.

Gous, R.M. \& Brand, T.S., 2008. Simulation models used for determining food intake and growth of ostriches: an overview. Austr. J. Exp. Agric. 48, 1266-1269.

Hoffman, L.C., 2012. Advances in the electrical stunning and bleeding of ostriches. Animal Welf. 21, 9-13 (Supplement 2).

Hoffman, L.C., Joubert, M., Brand, T.S. \& Manley, M., 2005. The effect of dietary fish oil rich in $\mathrm{n}-3$ fatty acids on the organoleptic, fatty acid and physicochemical characteristics of ostrich meat. Meat Sci. 70, 45-53.

Horbańczuk, J. \& Sales, J., 1998. Total lipid and cholesterol content and fatty acid composition of meat obtained from ostriches reared on a commercial farm. Anim. Sci. Pap. Rep. 16, 51-55.

Majewska, D., Jakubowska, M., Ligocki, M., Tarasewicz, Z., Szcezerbińska, D., Karamucki, T. \& Sales, J., 2009. Physicochemical characteristics, proximate analysis and mineral composition of ostrich meat as influenced by muscle. Food Chem. 117, 207-211.

Mellett, F.D., 1992. The ostrich as slaughter animal: Aspects of growth. Ph.D. Thesis, Stellenbosch University, South Africa. Available from http://hdl.handle.net/10019.1/2956.

Meyer, A., Cloete, S.W.P., Van Wyk, J.B. \& Van Schalkwyk, S.J., 2004. Is genetic selection for skin nodule traits of ostriches feasible? S. Afr. J. Anim. Sci. 34, 29-31 (Supplement 2).

NAMC(National Agricultural Marketing Council), 2010. The South African ostrich value chain: Opportunities for black participation and development of a programme to link farmers to markets. Available from http://www.namc.co.za/upload/all reports/Ostrich Value Chain Report.pdf, pp. 1-31. Accessed 20 July 2016.

Poławska, E., Marchewka, J., Cooper, R.G., Sartowska, K., Pomianowski, J., Jóźwik, A., Strzałkowska, N. \& Horbańczuk, J.O., 2011. The ostrich meat - an updated review. Animal Science Papers and Reports. 29, 89-97.

Sales, J. \& Hayes, J.P., 1996. Proximate, amino acid and mineral composition of ostrich meat. Food Chem. 56, 167-170.

Sales, J., Marais, D. \& Kruger, M., 1996. Fat content, caloric value, cholesterol content, and fatty acid composition of raw and cooked ostrich meat. J. Food Comp. Anal. 9, 85-89.

Sales, J. \& Oliver-Lyons, B., 1996. Ostrich meat: A review. Food Australia, 48, 504-511.

SCOT (2016) Grading Process at SCOT. Available from http://www.scot.co.za/Gradingsold.aspx. Accessed 12 July 2016.

Shapiro, S.S. \& Wilk, M.B., 1965. An analysis of variance test for normality (complete samples). In: Biometrika 52, 591611.

Snyman, N., 2016. A new approach to handing anti-nutritional factors: Soya bean meal as principal source of protein. In: AFMA matrix. Plaas, Centurion, Pretoria. 25, 30-31.

Viviers, S.F., 2015. Effect of dietary energy and protein on the production parameters of slaughter ostriches (Struthio camelus var. domesticus). MSc (Agric) thesis, University of Stellenbosch, South Africa.

Zyl, P.L., 2001. An economic evaluation of ostrich farming in the Oudtshoorn district. MSc (Agric) thesis, University of Stellenbosch, South Africa. 


\section{APPENDIX 1}

Composition of the vitamin and mineral premix used in the four ostrich feeding phases (pre-starter, starter, grower and finisher) formulated per ton of feed

\begin{tabular}{|c|c|c|c|}
\hline \multirow{2}{*}{$\begin{array}{l}\text { Ingredients } \\
\text { (Composition per unit of premix) }\end{array}$} & \multicolumn{3}{|c|}{ Stage of growth } \\
\hline & Units & Pre-starter \& starter & Grower \& finisher \\
\hline Vitamin A & IU & 15000000 & 12000000 \\
\hline Vitamin D3 & IU & 4000000 & 3000000 \\
\hline Vitamin E & $\mathrm{mg}$ & 60000 & 40000 \\
\hline Vitamin K3 stab & $\mathrm{mg}$ & 3000 & 3000 \\
\hline Vitamin B1 & $\mathrm{mg}$ & 5000 & 3000 \\
\hline Vitamin B2 & $\mathrm{mg}$ & 10000 & 8000 \\
\hline Vitamin B6 & $\mathrm{mg}$ & 8000 & 6000 \\
\hline Vitamin B12 & $\mathrm{mg}$ & 100 & 100 \\
\hline Niacin & $\mathrm{mg}$ & 100000 & 80000 \\
\hline Pantothenic acid & $\mathrm{mg}$ & 15000 & 12000 \\
\hline Folic acid & $\mathrm{mg}$ & 3000 & 2000 \\
\hline Biotin & $\mathrm{mg}$ & 300 & 200 \\
\hline Choline & $\mathrm{mg}$ & 800000 & 600000 \\
\hline Magnesium & $\mathrm{mg}$ & 50000 & 50000 \\
\hline Manganese & $\mathrm{mg}$ & 120000 & 120000 \\
\hline Iron & $\mathrm{mg}$ & 30000 & 25000 \\
\hline Zinc & $\mathrm{mg}$ & 120000 & 80000 \\
\hline Copper & $\mathrm{mg}$ & 8000 & 8000 \\
\hline Cobalt & $\mathrm{mg}$ & 300 & 100 \\
\hline lodine & $\mathrm{mg}$ & 2000 & 1000 \\
\hline Selenium & $\mathrm{mg}$ & 300 & 300 \\
\hline
\end{tabular}

*Recommendation: To make half ton of feed, divide premix pack into two parts 